to effectively poison larvæ hatching a month after the last spraying was applied.

President Glenn W. Herrick: Have you found eggs of the moths appearing in the spring?

Mr. W. H. Goodwin: Yes.

President Glenn W. Herrick: Where are they usually laid?

Mr. W. H. Goodwin: On the stems of the young grape cluster. The late moths of this brood deposit them on the small berries.

Mr. W. C. O'KANE: One of the most interesting and valuable features of this paper is the way it illustrates and emphasizes the importance of timeliness and thoroughness in the application of a remedy. Mr. Goodwin has not used any different remedies from what have been used before, but his success is due to the way he has worked out the manner of application and the time of it.

President GlenN W. Herrick: Mr. J. L. King will now present his paper.

\title{
NOTES ON THE CONTROL OF THE LESSER PEACH TREE BORER
}

By J. L. KInG, Cleveland, Ohio

(Withdrawn for publication elsewhere)

President Glenn W. Herrick: Is there any discussion or questions to ask Mr. King?

I was interested in one point namely, that the paper emphasized the fact that a substance effective in one territory under certain climatic conditions is sometimes of no avail in a wider territory or different climatic conditions.

I would like to ask if the asphaltum used was of the same grade as that used in California?

Mr. J. L. King: Yes sir. We wrote to the California people and bought from the same firm.

I want to emphasize the fact that had I drawn my conclusions in the fall of the same season that the asphaltum was applied, the results would not have appeared so destructive but instead I allowed the trees to remain through the winter so as to get the effect of freezing. This seems to have brought out fully the injurious effect of the asphaltum upon the bark.

President Glenn W. Herrick: How was that applied? In continuous rings?

Mr. J. L. KING: In some cases rings about the base of the trunk and in others over the wounded areas of the bark. 
Mr. E. P. Felt: I would like to ask Mr. King if he saw any evidences of the inner bark being penetrated or discolored by the asphaltum?

MR. J. L. KING: Not until late in the season did I get discoloring of the bark. When removing the bark it seemed to be very green during the first part of the season.

Mr. E. P. FELT: How were the trees the spring of the next year?

MR. J. L. KING: In the following spring the bark was brown and dead under the areas which were covered with the asphaltum.

In most every case where it was applied at the base of the trees as a preventive against Sanninoidea, the trees died or were very severely injured.

President Gienn W. Herrick: We will now listen to a paper by Mr. E. P. Felt.

\section{CLIMATE AND VARIATIONS IN THE HABITS OF THE CODLING MOTH}

By E. P. FeLT, Albany, N. Y.

Climatic differences appear to exert a considerable influence upon the habits and the type of injury caused by the codling moth if conditions obtaining in New York State the past two or three years are reliable criteria. Last summer 20 per cent or more of the crop in some orchards, and in others an even larger proportion bore the characteristic blemish we have termed "side injury." This is known among New York fruit-growers as "side worm" and by many of them is supposed to be the work of the second brood of the codling moth or that of some unknown insect. Dr. Quaintance informs us that this is the so-called "sting" of western fruit-growers.

The blemish, apparently first figured and described by John W. Lloyd in 1907 (Bul. 114, Ill. Agric. Expt. Sta.), has a diameter of about one-eighth of an inch and ordinarily may be found on the smoothest and most exposed face of the apple. There is a discoloration, sometimes reddish or reddish-brown, marked by a small central slit or puncture, the point where the young apple worm enters the fruit. This injury may be easily distinguished from small scab spots and certain types of hail damage, by the characteristics given above.

Observations the past season have shown that this type of injury, hitherto almost ignored, is due to the work of codling moth larvæ hatching from late-deposited eggs-that is those laid the latter part of June or early in July. At this time the fruit has attained considerable size, being an inch or so in diameter, is much smoother than the 